\title{
ANALISIS FAKTOR-FAKTOR YANG BERHUBUNGAN DENGAN KUALITAS PENGELOLAAN PEMBELAJARAN KLINIK
}

\author{
Ahmad, Erwan ${ }^{1}$, Yani, Achir ${ }^{2}$, Azidin, Yustan ${ }^{3}$ \\ ${ }^{1}$ Mahasiswa Magister Ilmu Keperawatan Universitas Muhammadyah Banjarmasin \\ ${ }^{2}$ Staff Dosen Fakultas Ilmu Keperawatan Universitas Indonesia \\ ${ }^{3}$ Staff Dosen Pascasarjana Universitas Muhammadyah Banjarmasin
}

Email : erwan.ea@gmail.com

\begin{abstract}
Abstrak
Latar Belakang: Pembelajaran klinik merupakan pembelajaran berbasis pengalaman dimana mahasiswa diharapkan mampu mengaplikasikan teori yang diperoleh dari akademik pada kasuskasus nyata di klinik. Manfaat pembelajaran klinik adalah mendapatkan pengalaman nyata untuk mencapai kemampuan profesional yang meliputi intelektual, teknikal, dan interpersonal. Penelitian ini bertujuan untuk mengetahui faktor-faktor yang berhubungan dengan kualitas pembelajaran klinik meliputi factor kompetensi pembimbing, pengaturan bimbingan, metode pembelajaran, lingkungan pembelajaran, dan lahan praktik.

Metode: Jenis penelitian yang digunakan adalah penelitian kuantitatif dengan rancangan deskriptif korelasi bersifat cross sectional. Sampel pada penelitian ini adalah mahasiswa profesi ners berjumlah 84 orang dengan teknik Total Sampling. Pengumpulan data menggunakan lembar kuesioner. Analisis data yang digunakan dalam penelitian ini adalah regresi logistic ganda.

Hasil: Uji statistik menunjukkan bahwa terdapat empat hubungan dengan kualitas pembelajaran klinik yaitu komptensi pembimbing, pengaturan bimbingan, metode pembelajaran dan lingkungan pembelajaran dengan $p$ value $<0,05$ dan faktor yang paling dominan adalah kompetensi pembimbing dengan nilai probability sebesar 2,820.

Kesimpulan :Bidang manajemen pendidikan perlu memperhatikan kompetensi dosen dan lingkungan pembelajaran terhadap kualitas pembelajaran klinik.
\end{abstract}

Kata Kunci : Pembelajaran Klinik, Kompetensi 


\section{PENDAHULUAN}

Rumah sakit memiliki tiga fungsi utama yaitu fungsi pelayanan, pengembangan IPTEK dan ekonomi. Peraturan Menteri Kesehatan Tahun 1988 Nomor 159b menjelaskan bahwa Rumah Sakit umum juga digunakan sebagai wahana pendidikan disebut sebagai "Teaching Hospital" atau Rumah Sakit Pendidikan (RSP). Rumah Sakit Pendidikan adalah rumah sakit yang mempunyai fungsi sebagai tempat pendidikan, penelitian, dan pelayanan kesehatan secara terpadu dalam bidang pendidikan kedokteran, pendidikan berkelanjutan, dan pendidikan kesehatan lainnya secara multiprofesi (Undang-Undang Republik Indonesia Nomor 20 Tahun 2013 Pasal 1).

Rumah Sakit Pendidikan bersama Institusi Pendidikan bertanggung jawab dalam pencapaian kompetensi mahasiswa melalui perencanaan pembelajaran klinik. (Peraturan Pemerintah Republik Indonesia Nomor 93 Tahun 2015). Pembelajaran klinik merupakan pembelajaran berbasis pengalaman, peserta didik diharapkan mampu mengaplikasikan teori yang diperoleh dari akademik pada kasus-kasus nyata di klinik (Kusuma, 2017).

Pembelajaran klinik keperawatan bertujuan untuk memantapkan peran dan fungsi mahasiswa keperawatan seperti menguasai konsep dan teori keperawatan dalam pengelolaan asuhan keperawatan kepada klien sehingga dapat menghasilkan tenaga profesional. Pembelajaran yang berkualitas akan menghasilkan lulusan yang handal dan kompeten begitu pun sebaliknya. Dampak pembelajaran yang tidak berkualitas bagi mahasiswa keperawatan di Inggris yaitu menurunnya kualitas bimbingan, praktik interdisipliner kurang, kesempatan yang terlewatkan untuk berbagi pembelajaran, tidak fokus dan motivasi belajar menurun serta tidak tercapainya kompetensi (Donley \& Norman , 2018).

Hardisman (2009) berpendapat salah satu upaya yang dapat dilakukan untuk meningkatkan capaian kualitas pembelajaran klinik keperawatan adalah dengan melakukan penataan pengelolaan pembelajaran klinik meliputi kemampuan dan kompetensi pembimbing, pengaturan bimbingan, dan kolaborasi dengan tempat praktik. Faktor lainnya yang menunjang dalam capaian pembelajaran ialah metode bimbingan dan lingkungan belajar. Pengelolaan pembelajaran klinik keperawatan yang baik akan menjamin mahasiswa untuk memperoleh pengalaman nyata di tatanan sesuai dengan tujuan pembelajaran dan pencapaian kompetensi yang diharapkan (Hellen \& Smith, 2011).

Data kelulusan UKNI (Uji Kompetensi Ners Nasional) periode IV Tahun 2015 dari total peserta yang mengikuti Uji Kompetensi Nasional yaitu sebanyak 10.009 mahasiswa program profesi ners, teridentifikasi sejumlah 6.223 peserta ujian $(62.17 \%)$ dinyatakan kompeten dan sebanyak $3.786 \quad(37.83 \%)$ 
dinyatakan tidak kompeten. Pada Uji Kompetensi Ners Nasional periode V Tahun 2016 angka kelulusan mahasiswa mulai mengalami penurunan. Total peserta ujian yaitu 14.873 mahasiswa, dan yang teridentifikasi kompeten hanya sebanyak $7.466(50.19 \%)$ sedangkan sisanya sebanyak 7.407 (49.81\%) dinyatakan tidak kompeten.

Penurunan tingkat kelulusan mahasiwa dalam uji kompetensi berlanjut sampai dengan periode VIII tahun 2017. Periode VI tahun 2016 hanya sebesar 47,16\% yang dinyatakan kompeten, periode VII tahun 2017 menurun kembali sebesar $44.62 \%$ yang dinyatakan kompeten dan periode VIII tahun 2017 hanya sebesar $41.12 \%$ mahasiswa yang dianggap kompeten. Hasil evaluasi UKNI (Uji Kompetensi Ners Indonesia) periode XI tahun 2018 juga menunjukkan hasil yang tidak jauh berbeda, dimana angka lulusan ners yang tidak kompeten lebih besar dibandingkan angka lulusan yang kompeten. Lulusan yang tidak kompeten berjumlah 8.426 orang sedangkan yang kompeten hanya berjumlah 5.975 orang (ukners.dikti.go.id). Rendahnya persentase kelulusan dan penurunan jumlah mahasiswa pada ujian kompetensi ners, selayaknya menjadi bahan evaluasi.

Lulusan perawat yang professional didukung oleh keberadaan pembimbing klinik yang menjalankan peran dan fungsinya pemilihan, metode pembelajaran yang tepat, rumah sakit pendidikan yang memadai, serta perawat rumah sakit yang mengembangkan budaya komunitas professional keperawatan, menjadi faktor utama dalam penyelenggaraan pembelajaran klinik. Hal tersebut didukung oleh penelitian Astuti (2010) yang mengungkapkan terdapat hubungan positif yang signifikan antara manajemen pembelajaran klinik dengan kinerja praktik, makin tinggi manajemen pembelajaran klinik makin meningkatkan kinerja praktik klinik mahasiswa.

Studi awal dilakukan peneliti terhadap 10 mahasiswa program profesi Ners FKIK Universitas Muhammadiyah Banjarmasin, 6 mahasiswa keperawatan yang diwawancarai, mengatakan bahwa pembimbing dalam hal membimbing mahasiswa masih kurang, mahasiswa dapat berinteraksi dengan pembimbing disaat pre dan post conference, diluar itu jarang sekali mahasiswa mendapatkan bimbingan dari pembimbing. Sebanyak 3 dari 7 mahasiswa menyebutkan tidak diberikan orientasi dan pengarahan mengenai bimbingan. Sebanyak 6 diantaranya mengatakan bahwa mereka merasa cemas jika mereka harus menghadapi lingkungan baru (misalnya ketika pindah stase). Hasil wawancara mengenai metode pembelajaran, mereka mengatakan yang dilakukan berupa bedside teaching, DOPS, seminar dan mini cex serta melakukan asuhan keperawatan.

Berdasarkan fenomena tentang berbagai faktor dalam pengelolaan pembelajaran klinik berdampak terhadap pencapaian kompetensi 
mahasiswa, maka dirasakan penting untuk meneliti: "Analisis Faktor-Faktor yang Berhubungan dengan Kualitas Pengelolaan Pembelajaran Klinik”

\section{METODE PENELITIAN}

Penelitian ini menggunakan metode riset kuantitatif dengan rancangan deskriptif korelasi bersifat cross sectional. Penelitian ini untuk menggambarkan serta menganalisis Faktor-Faktor Yang Mempengaruhi Pembelajaran Klinik Mahasiswa Ners Universitas Muhammadiyah Banjarmasin. Populasi dalam penelitian ini adalah semua Mahasiswa Program Ners UMB angkatan 2018 berjumlah 84 responden. Teknik pengambilan sampel yang digunakan adalah Total Populasi, yaitu pengambilan sampel dengan menggunakan semua anggota populasi. Besar sampel penelitian ini adalah 84 responden. Penelitian ini dilakukan di lingkungan Universitas Muhammadiyah Banjarmasin dari November 2019 s/d Januari 2020 dengan menggunakan alat ukur kuesioner untuk mengkaji faktor-faktor yang mempengaruhi pembelajaran klinik dan kualitas pembelajaran klinik.

\section{HASIL}

\section{a. Analisa Univariat}

Analisa dibuat sesuai dengan apa yang didapatkan dari responden meliputi kompetensi pembimbing, pengaturan pembimbing, metode pembelajaran, lingkungan pembelajaran, lahan praktik, dan kualitas pembelajaran. Uraian analisa univariat adalah sebagai berikut:

\subsection{Kompetensi dan Pengaturan pembimbing yang digambarkan dalam distribusi mahasiswa ners UMB.}

\section{Tabel 3.1 Distribusi kompetensi dan pengaturan pembimbing berdasarkan mahasiswa ners UMB $(n=84)$}

\begin{tabular}{ccc}
\hline $\begin{array}{c}\text { Kompetensi } \\
\text { Pembimbing }\end{array}$ & F & \% \\
\hline Baik & 71 & 84,5 \\
Kurang & 13 & 15,5 \\
\hline Total & $\mathbf{8 4}$ & $\mathbf{1 0 0}$ \\
\hline Pengaturan & $\mathrm{F}$ & $\%$ \\
Bimbingan & & 65,5 \\
\hline Baik & 55 & 34,5 \\
Kurang & 29 & $\mathbf{1 0 0}$ \\
\hline Total & $\mathbf{8 4}$ & \\
\hline
\end{tabular}

Data yang ditunjukan pada Tabel 3.1 dari 84 responden, diketahui kompetensi pembimbing berdasarkan mahasiswa ners UMB dengan katagori baik ada 71 responden (84,5\%), sedangkan untuk pengaturan bimbingan berdasarkan mahasiswa ners UMB dengan katagori baik ada 55 responden $(65,5 \%)$.

\subsection{Metode dan Lingkungan} pembelajaran yang digambarkan 
dalam distribusi mahasiswa ners

UMB.

Tabel 3.3 Distribusi metode dan lingkungan pembelajaran berdasarkan mahasiswa ners

$$
\text { UMB }(n=84)
$$

\begin{tabular}{ccc}
$\begin{array}{c}\text { Metode } \\
\text { Pembelajaran }\end{array}$ & F & \% \\
\hline Baik & 41 & 48,8 \\
Kurang & 43 & 51,2 \\
\hline Total & $\mathbf{8 4}$ & $\mathbf{1 0 0}$ \\
\hline Lingkungan & F & $\%$ \\
Pembelajaran & & \\
\hline Baik & 43 & 51,2 \\
Kurang & 41 & 48,8 \\
\hline Total & $\mathbf{8 4}$ & $\mathbf{1 0 0}$
\end{tabular}

Tabel 3.2 menunjukkan data bahwa dari 84 responden, diketahui metode pembelajaran berdasarkan mahasiswa ners UMB dengan katagori kurang ada 43 responden $(51,2 \%)$, sedangkan untuk data lingkungan pembelajaran berdasarkan mahasiswa ners UMB dengan katagori baik ada 43 responden $(51,2 \%)$.

\subsection{Lahan praktik dan Kualitas pembelajaran klinik yang digambarkan dalam distribusi mahasiswa ners UMB.}

Tabel 3.5 Distribusi lahan praktik berdasarkan mahasiswa ners UMB $(n=84)$

\begin{tabular}{ccc}
\hline $\begin{array}{c}\text { Lahan } \\
\text { Praktik }\end{array}$ & F & \% \\
\hline Baik & 64 & 76,2 \\
Kurang & 20 & 23,8 \\
\hline Total & $\mathbf{8 4}$ & $\mathbf{1 0 0}$ \\
\hline Kualitas & F & $\%$ \\
Pembelajaran & & \\
Klinik & & \\
\hline Baik & 47 & 56,0 \\
\hline Kurang & 37 & 44,0 \\
\hline Total & $\mathbf{8 4}$ & $\mathbf{1 0 0}$ \\
\hline
\end{tabular}

Data yang ditunjukan pada tabel 3.3 dari 84 responden, diketahui lahan praktik berdasarkan mahasiswa ners UMB dengan katagori baik ada 64 responden (76,2\%). Tabel 3.3 juga menunjukkan kualitas pembelajaran klinik berdasarkan mahasiswa ners UMB dengan katagori baik ada 47 responden $(56 \%)$.

\section{b. Analisis Bivariat}

\subsection{Hubungan}

Faktor-Faktor

Pembelajaran Klinik dengan Kualitas Pembelajaran Klinik.

Tabel 3.4 Hubungan Faktor-Faktor Pembelajaran Klinik dengan Kualitas Pembelajaran Klinik.

$\begin{array}{ccc}\text { No } & \text { Variabel } & \text { Variabel Dependen } \\ & \text { Independen } & (\mathrm{Y}) \\ & (\mathrm{X}) & \text { Kualitas }\end{array}$


Pembelajaran Klinik

\begin{tabular}{llcc}
\cline { 3 - 3 } & & $\begin{array}{c}\text { Koefiseien } \\
\text { Korelasi }\end{array}$ & $\begin{array}{c}\boldsymbol{P} \\
\text { Value }\end{array}$ \\
\hline 1. & $\begin{array}{l}\text { Komptensi } \\
\text { pembimbing }\end{array}$ & 0,416 & 0,000 \\
2. & $\begin{array}{l}\text { Pengaturan } \\
\text { bimbingan }\end{array}$ & 0,364 & 0,001 \\
3. & $\begin{array}{l}\text { Metode } \\
\text { pembelajaran }\end{array}$ & 0,234 & 0,026 \\
4. & $\begin{array}{l}\text { Lingkungan } \\
\text { Pembelajaran }\end{array}$ & $-0,194$ & 0,076 \\
5. & Lahan praktik & $-0,46$ & 0,681
\end{tabular}

$\mathbf{N}=\mathbf{8 4}$

Korelasi X1 dan Y memiliki nilai 0,416 yang dapat dikategorikan memiliki hubungan yang sedang antara kompetensi pembimbing terhadap kualitas pembelajaran klinik. Berdasarkan uji signifikasi hasilnya menunjukkan nilai 0,000 yang berarti asosiasi kedua variabel adalah signifikan.

Korelasi X2 dan Y memiliki nilai 0,365 yang dapat dikategorikan memiliki hubungan yang lemah antara pengaturan bimbingan terhadap kualitas pembelajaran klinik. Berdasarkan uji signifikasi hasilnya menunjukkan nilai 0,001 yang berarti asosiasi kedua variabel adalah signifikan.

Korelasi X3 dan Y memiliki nilai 0,243 yang dapat dikategorikan memiliki hubungan yang lemah antara metode pembelajaran terhadap kualitas pembelajaran klinik. Berdasarkan uji signifikasi hasilnya menunjukkan nilai 0,026 yang berarti asosiasi kedua variabel adalah signifikan.
Korelasi $\mathrm{X} 4$ dan $\mathrm{Y}$ memiliki nilai 0,194 yang dapat dikategorikan memiliki hubungan yang sangat lemah antara lingkungan pembelajaran terhadap kualitas pembelajaran klinik. Berdasarkan uji signifikasi hasilnya menunjukkan nilai 0,076 yang berarti asosiasi kedua variabel adalah tidak signifikan.

Korelasi X5 dan Y memiliki nilai -0,46 yang dapat dikategorikan memiliki hubungan yang sedang antara lahan praktik terhadap kualitas pembelajaran klinik. Berdasarkan uji signifikasi hasilnya menunjukkan nilai 0,681 yang berarti asosiasi kedua variabel adalah tidak signifikan.

\section{c. Analisis Multivariat}

\subsection{Ringkasan Hasil Analisis Multivariat Menggunakan Regresi Logistik Metode Enter}

Hasil pengukuran menggunakan regresi Logistik Metode Enter pertama ditemukan ada empat variabel independen nilai $P$ value uji wald (Sig) $<0,05$ dari 5 variabel, artinya empat variabel mempunyai pengaruh parsial yang signifikan terhadap $\mathrm{Y}$ di dalam model sedangkan satu variabel tidak signifikan. Faktor yang tidak signifikan, adalah factor Lahan Praktik. Karena ada parameter yang tidak signifikan maka perlu dilakukan seleksi model terbaik. Seleksi ini dlakukan sampai Regresi Logistik Metode Enter 6, dimana 
lahan praktik memiliki nilai signifikan sampai pada perhitungan kelima, sehingga factor lahan praktik dikeluarkan proses seleksi. Hasil seleksi terakhir ditunjukkan pada tabel dibawah ini,

Tabel 3.5 Ringkasan Hasil Analisis Multivariat Menggunakan Regresi Logistik Metode Enter 6

\begin{tabular}{lccccc}
\hline \multicolumn{1}{c}{ Variabel } & $\boldsymbol{B}$ & $\boldsymbol{P}$ & OR & \multicolumn{2}{c}{$\mathbf{9 5 \% C I}$} \\
\cline { 5 - 6 } & & Value & & Lower & Upper \\
\hline $\begin{array}{l}\text { Komptensi } \\
\text { pembimbing }\end{array}$ & 2,820 & 0,013 & 16,784 & 1,806 & 155,984 \\
& & & & & \\
Pengaturan & 1,306 & 0,023 & 3,691 & 1,194 & 11,408 \\
bimbingan & & & & & \\
& & & & & \\
Metode & 1,218 & 0,027 & 3,380 & 1,147 & 9,960 \\
pembelajaran & & & & & \\
Lingkungan & $-1,902$ & 0,049 & 0,336 & 0,113 & 0,996 \\
Pembelajaran & & & & & \\
\hline Konstanta & $\mathbf{- 1 , 1 6 4}$ & $\mathbf{0 , 0 1 9}$ & $\mathbf{0 , 3 1 2}$ & & \\
\hline
\end{tabular}

$\mathrm{X} 1$ atau kompetensi pembimbing mempunyai nilai $0,013<0,05$ sehingga menolak $\mathrm{H} 0$ atau yang berarti kompetensi pembimbing memberikan pengaruh parsial yang signifikan terhadap kualitas pembelajaran klinik.

$\mathrm{X} 2$ atau pengaturan bimbingan mempunyai nilai $0,023<0,05$ sehingga menolak $\mathrm{H} 0$ atau yang berarti pengaturan bimbingan memberikan pengaruh parsial yang signifikan terhadap kualitas pembelajaran klinik.
X3 atau metode pembelajaran mempunyai nilai $0,027<0,05$ sehingga menolak H0 atau yang berarti metode pembelajaran memberikan pengaruh parsial yang signifikan terhadap kualitas pembelajaran klinik. X4 atau lingkungan pembelajaran mempunyai nilai $0,049<0,05$ sehingga menolak $\mathrm{HO}$ atau yang berarti metode pembelajaran memberikan pengaruh parsial yang signifikan terhadap kualitas pembelajaran klinik.

Faktor paling dominan adalah variabel komptensi pembimbing dengan nilai probability sebesar 2,820 akan tetapi tidak berdiri sendiri karena dipengaruhi oleh pengaturan bimbingan dan metode pembelajaran dengan nilai oods ratio yang saling berinteraksi sampai didapatkan permodelan terakhir.

\section{PEMBAHASAN}

\subsection{Kompetensi pembimbing terhadap} kualitas pengelolaan pembelajaran klinik.

Hasil penelitian pada Tabel 3.1 menunjukkan bahwa kompetensi pembimbing dalam kategori baik sebesar 84,5\% dan terlihat pada tabel 3.4 mempunyai hubungan yang signifikan terhadap kualitas pembelajaran klinik $(\mathrm{Sig})<0,05$ serta terlihat dari OR di tabel 3.5 sebesar 16,784 dimana ini menunjukkan varibel kompetensi pembimbing sangat erat kaitannya dengan kualitas pembelajaran klinik. 
Carol \& Shafranske (2017) mengatakan bahwa pentingnya kompetensi yang dimiliki pembimbing merupakan komponen penting dalam proses tersirat pada praktik klinik. Sejalan dengan itu penelitian Kim (2018) juga mengatakan pembimbing yang memiliki kompeten dan karakter moral yang baik merupakan panutan bagi setiap individu.

Asumsi peneliti dari hasil penelitian bahwa untuk mendapatkan kualitas pembelajaran klinik optimal perlu adanya pembimbing yang berkompeten. Kompetensi sebagai pembimbing klinik diperoleh seseorang tidak secara kebetulan melainkan diperoleh melalui proses pendidikan yaitu pendidikan profesi keperawatan dan pendidikan profesi kePembimbingan atau kependidikan serta berupa pelatihanpelatihan.

\subsection{Pengaturan bimbingan terhadap kualitas pengelolaan pembelajaran klinik}

Hasil pada tabel 3.1 menunjukkan bahwa pengaturan bimbingan dalam kategori baik sebesar $65,5 \%$ dan kurang $34,5 \%$ serta pada tabel 3.4 mempunyai hubungan yang signifikan terhadap kualitas pembelajaran klinik $($ Sig $)<0,05$. Nilai OR yang sebesar 3,691 dan nilai B 1,306 pada tabel 3.5 juga menunjukkan varibel pengaturan bimbingan berpengaruh positif terhadap kualitas pembelajaran klinik.
Asumsi peneliti yang dapat disimpulkan bahwa variabel pengaturan bimbingan termasuk penting dalam kualitas pembelajaran klinik. Proses pembelajaran klinik melibatkan pembimbing klinik, pasien dan mahasiswa. Peran ketiganya harus jelas sehingga terjadi hubungan yang harmonis dalam menempuh proses pembelajaran klinik yang begitu kompleks. Untuk mencapai tujuan pembelajaran klinik diperlukan manajemen bimbingan klinik yang baik. Bimbingan tersebut dapat membantu mahasiswa dalam memperoleh gambaran dan pandangan yang jelas serta mendapatkan pendidikan yang sesuai dengan kebutuhan, bakat, minat dan kemampuan yang dimiliki sehingga dapat menentukan cara yang efektif dan efisien dalam menyelesaikan bidang pendidikan yang telah dipilih agar tercapai hasil yang diharapkan.

Hasil penelitian (Courtney, Joyce, Padden, \& Bigley, 2019) mengungkapkan bimbingan klinik erat kaitannya dengan proses pembentukan dan penyelesaian tentang kemungkinan-kemungkinan dalam klinis agar ia dapat menentukan pilihan yang tepat. Penelitian (Jacob \& Struyf, 2015) mengungkapkan meningkatkan integritas managemen bimbingan baik ada beberapa faktor yaitu persepsi tugas yang diberikan pembimbing, profesionalisasi, komunikasi pembimbing dan dukungan akademik dalam menjalankan proses bimbingan. 


\subsection{Metode pembelajaran terhadap kualitas pengelolaan pembelajaran klinik}

Hasil penelitian menunjukkan bahwa variabel metode pembelajaran merupakan salah satu yang ada hubungan signifikan terhadap kualitas pembelajaran klinik dibuktikan pada tabel 3.4 nilai $($ Sig) $<0,05$. Pada tabel 3.5 juga terlihat nilai OR yang sebesar 3,380 dan mempunyai nilai B sebesar 1,218 menunjukkan variabel metode pembelajaran berpengaruh positif terhadap kualitas pembelajaran klinik.

Penelitian (Godderidge , Wall, \& Franklin, 2019) yang menyatakan bahwa metode pembelajaran yang effisien dengan cara mengurangi 30\% waktu yang dihabiskan dibangku kuliah dan memperbanyak simulasi klinik dengan meningkatkan keterlibatan mahasiswa. Sejalan dengan penelitian (Foster \& Dornan, 2003) mengungkapkan mahasiswa yang mendapatkan metode pembelajaran yang baik akan mudah dapat memahami tujuan pembelajaran dan memberikan pengalaman belajar klinis yang relevan sesuai dengan pendidikan.

Asumsi peneliti memang variabel metode pembelajaran berkontribusi besar terhadap kualitas pembelajaran. Dimana metode tersebut harus sesuai dengan kemampuan pengalaman dan karakteristik mahasiswa, sesuai dengan tujuan pembelajaran yang telah direncanakan, sesuai dengan sumber-sumber dan keterbatasan lahan praktek serta sesuai dengan filosofi keperawatan.

\subsection{Lingkungan pembelajaran terhadap kualitas pengelolaan pembelajaran klinik}

Hasil penelitian menunjukkan bahwa variabel lingkungan pembelajaran ada hubungan signifikan terhadap kualitas pembelajaran klinik dibuktikan pada tabel 3.4 dengan ( $\mathrm{Sig})<0,05$ dan berpengaruh negatif terhadap kualitas pembelajaran klinik dengan correlation coefficient $-0,194$ dan nilai probability -1,902 pada tabel 3.5.

Asumsi peneliti variabel lingkungan pembelajaran ada hubungan dengan kualitas pembelajaran kuncinya ada di resiliensi dan clinical learning experience mahasiswa. Resiliensi adalah kemampuan individu untuk menyesuaikan diri dan beradaptasi terhadap perubahan, tuntutan, dan kekecewaan yang muncul dalam kehidupan. Individu dengan Resiliensi yang baik memahami bahwa kesalahan bukanlah akhir dari segalanya. Jika Resiliensi meningkat maka individu akan mampu untuk mengatasi kesulitan apapun yang muncul didalam kehidupan (Wilda, Nazriati \& Firdaus, 2016). Setiap mahasiswa yang ditempatkan di lingkungan pembelajaran yang kurang dimana fasilitas sarana dan prasarana tidak memadai, interaksi lingkungan sosial yang sulit dilakukan memicu dalam diri mahasiswa untuk lebih 
meningkatkan atau mencari cara untuk menjadi lebih baik sehingga lingkungan yang kurang tetap tidak menjadikan kualitas pembelajaran klinik menjadi buruk dan malah menjadi lebih baik.

Pada penelitian (Trigueros, et al., 2019) terdapat lima komponen untuk menjadikan individu yang resilien sehingga dapat bertahan serta bangkit kembali dalam situasi yang sulit. Komponen-komponen tersebut yaitu meaning fulness disebut juga dengan memiliki tujuan dalam hidup, ini merupakan komponen terpenting, karena hidup tanpa tujuan akan sia-sia. Yang kedua perseveran yaitu suatu tindakan untuk bertahan dalam menghadapi kesulitan, untuk membangun ketahanan ini dengan menekuni rutinitas dengan positif.

\subsection{Lahan praktik terhadap kualitas pengelolaan pembelajaran klinik}

Hasil penelitian menunjukkan bahwa lahan praktik tidak mempunyai hubungan yang signifikan terhadap kualitas pembelajaran klinik $(\mathrm{Sig})>0,05$ dan nilai B 0,918 ini menunjukkan varibel lahan praktik berpengaruh negatif terhadap kualitas pembelajaran klinik.

Rumah sakit berdasarkan afilasi pendidikan terdiri atas dua jenis yaitu rumah sakit pendidikan dan rumah sakit non pendidikan. Hasil penelitian (Najar, Amiresmaeili , Nekoei, \& Tabatabaee , 2018) Rumah sakit pendidikan memang mempunyai kelebihan serta fasilitas teknologi kedokteran yang mempuni dibandingkan rumah sakit yang non pendidikan, akan tetapi rumah sakit non pendidikan selalu berbenah demi meningkatkan mutu pelayanan dan keselamatan pasien. Sejalan dengan penelitian penelitian yang dilakukan oleh (Suwayri, 2016) bahwa penempatan mahasiswa di rumah sakit non-pendidikan biasa dilakukan. Rumah sakit non-pendidikan juga berusaha memenuhi kebutuhan mahasiswa yang sedang berpraktik disana.

Asumsi peneliti dapatkan dari beberapa literatur dan beberapa jurnal serta hasil penelitian, peneliti memiliki pendapat bahwa lahan praktik memang tidak ada hubungan dengan kualitas pembelajaran klnik. Rumah sakit pendidikan memang lebih banyak mendapatkan pembelajaran klinik daripada di rumah sakit non pendidikan dikarenakan tatanan pelayanan yang lebih kompleks dan banyaknya kasus-kasus yang bervariasi didapatkan, akan tetapi rumah sakit nonpendidikan tidak kalah jauh karena mereka semaksimal memenuhi apa yang akan dicapai mahasiswa sehingga kualitas pembelajaran klinik akan sama dengan penempatan mahasiwa dirumah sakit pendidikan serta emosi mahasiswa terhadap lahan praktik (feel practice) yang menjadikan lahan praktik tidak ada hubungan dengan kualitas pembelajaran klinik.

\section{SIMPULAN}


Hasil penelitian ini mendapatkan hasil bahwa pertama terdapat hubungan signifikan positif antara kompetensi pembimbing dengan kualitas pengelolaan pembelajaran klinik dengan (Sig) $<0,05$ dan nilai OR yang sebesar 12,614. Kedua terdapat hubungan signifikan positif antara pengaturan bimbingan dengan kualitas pengelolaan pembelajaran klinik dengan $(\mathrm{Sig})<0,05$ dan nilai OR yang sebesar 3,480. Ketiga terdapat hubungan signifikan positif antara metode pembelajaran dengan kualitas pengelolaan pembelajaran klinik dengan $(\mathrm{Sig})<0,05$ dan nilai OR yang sebesar 2,991. Keempat terdapat hubungan signifikan negatif antara lingkungan pembelajaran dengan kualitas pengelolaan pembelajaran klinik dengan (Sig) $<0,05$. Kelima tidak terdapat hubungan signifikan antara lahan praktik dengan kualitas pengelolaan pembelajaran klinik dengan (Sig) $>0,05$. Keenam faktor yang paling dominan hubungannya dengan kualitas pengelolaan pembelajaran klinik yaitu kompetensi pembimbing dengan nilai probability sebesar 2,535.

Hasil penelitian ini juga memberikan saran kepada bidang manajemen pendidikan perlu memperhatikan kompetensi dosen pada saat rekrutmen dosen dilakukan berdasarkan pemenuhan persyaratan kualifikasi. Perlu penelitian lebih lanjut menggunakan riset kualitatif untuk mengeksplor aspek lingkungan pembelajaran yang mengkontribusi pada kualitas pembelajaran klinik. guna mencapai hasil pembelajaran (learning outcome) sebagai lulusan ners.

\section{DAFTAR PUSTAKA}

Astuti, I. M. (2010). Pembelajaran Praktik Klinik Keperawatan Mahasiswa Tingkat II Akademi Keperawatan Kosgoro Mojokerto Di Rumah Sakit Tipe A. Tesis: Universitas Sebelas Maret.

Carol, F., \& Shafranske, E. (2017). Competency-based Clinical Supervision: Status, Opportunities, Tensions, and the Future. Australian Psychologist, 86-93.

Courtney, P., Joyce, K., Padden, D., \& Bigley, M. B. (2019). A checklist for faculty and preceptor to enhance the nurse practitioner student clinical experience. Journal of the American Association of Nurse Practitioners, 31(10): 1 .

Donley , C., \& Norman , K. (2018). Nursing Student Perspective On A Quality Learning Environment in General Practice. Primary Health Care, Vol 28 Issue 4, p36-42. 7p.

Foster, M., \& Dornan, T. (2003). Selfdirected, integrated clinical learning through a sign-up system. Med Educ, 659-9.

Godderidge , J. G., Wall, B., \& Franklin, S. (2019). Creating an Efficient Learning Model: Students' Perceptions and Outcomes of an Active Learning Fixed Prosthodontics Course. J Dent Educ, 1076-1080.

Hardisman. (2009). Model Bimbingan pada Pendidikan Klinik dan Relevansinya pada Pendidikan Kedokteran dan Kesehatan di Indonesia. Majalah kedokteran Andalas, Vol. 33 No. 2 Juli-Desember 2009.

Hellen, T. A., \& Smith, P. (2011). xperiences of supernumerary status and the hidden curriculum in nursing: a new twist in the theory-practice gap? 20:847-55: Clin Nurs. 
Jacob, K., \& Struyf, E. (2015). A First Step Toward a Comprehensive Model of Integrated Socio-emotional Guidance: Investigating the Effect of Teachers' Task Perception and a Supportive Network at School. The Journal of Educational Research , 95-111.

Kusuma, A. (2017). Peningkatan Pengetahuan dan Keterampilan CI Sebelum dan Setelah Pelatihan Bedside Teaching dan One Minute Preceptor. Tesis: Universitas Gadjah Mada.

Najar, V., Amiresmaeili , M., Nekoei, M. M., \& Tabatabaee, S. S. (2018). The design of an estimation norm to assess nurses required for educational and non-educational hospitals using workload indicators of staffing need in Iran. Hum Resour Health, 42.

Nursalam , \& Effendi, F. (2014). Pendidikan Dalam Keperawatan. Jakarta: Salemba Medika.

Suwayri, A. S. (2016). Impact Of Students in Non-Teaching Hospitals. Clin Teach, 14(2):114-118.

Trigueros, R., Parra, J. M., Cangas, A. J., Bermejo, R. M., Ferrándiz, C., \& Liria, R. L. (2019). Influence of Emotional Intelligence, Motivation and Resilience on Academic Performance and the Adoption of Healthy Lifestyle Habits among Adolescents. Int J Environ Res Public Health. 